\title{
Climate change and the unsustainable urbanism in the municipality of João Pessoa, PB, Brazil
}

Mudanças climáticas e o urbanismo insustentável no município de João Pessoa, Paraíba, Brasil

Letícia Palazzi Perez ${ }^{\mathrm{a}}$

Andréa Leandra Porto Sales ${ }^{b}$

José Augusto Ribeiro da Silveirac

${ }^{a}$ Doutora, Professora Visitante no Departamento e no Programa de Pós Graduação em Arquitetura e Urbanismo da Universidade Federal da Paraíba, João Pessoa, PB, Brasil E-mail: leticia.palazzi@gmail.com

${ }^{b}$ Doutora, Professora Adjunta no Departamento de Geografia da Universidade Federal da Paraíba, João Pessoa, PB, Brasil E-mail: andreaportosales@gmail.com

'Doutor, Professor no Departamento e no Programa de Pós Graduação em Arquitetura e Urbanismo da Universidade Federal da Paraíba, Vice Coordenador do Programa de Pós Graduação em Arquitetura e Urbanismo da Universidade Federal da Paraíba, João Pessoa, PB, Brasil E-mail: ctlaurbe@gmail.com

doi:10.18472/SustDeb.v11n2.2020.32330

\begin{abstract}
In the scope of urban space production, Brazilian urban policy, despite pointing out in its guidelines the struggle for the right to the city, seems indifferent to the impacts of real estate speculation on ecosystems. Given the context of the climate emergency, there is an urgent need to align urban and environmental policy for planning cities adapted to climate change. This work presents, based on spatial data from the recent deforestation of the city of João Pessoa, the legal and socioenvironmental characteristics of the urban expansion of the city and how the municipal urban and environmental policy has catalyzed processes of socioenvironmental injustice. It appears that planning and management are limited to following the trends signaled by the real estate market and that pressure ecosystems, especially in the southern portion of the municipality, and also that democratic arrangements are forged to make society's role in defending ecosystems unfeasible.
\end{abstract}

Keywords: Urban Policy. Environmental Policy. Urban Sprawl. Climate Change.

\section{RESUMO}

No âmbito da produção do espaço urbano, a política urbana brasileira apesar de assinalar em suas diretrizes a luta pelo direito à cidade, parece indiferente aos impactos da especulação imobiliária sobre os ecossistemas. Dado o contexto da emergência climática, é urgente alinhar a política urbana e 
ambiental para o planejamento de cidades adaptadas às mudanças do clima. Este trabalho apresenta, a partir de dados espaciais do desflorestamento recente da cidade de João Pessoa, as características jurídicas e socioambientais da expansão urbana da cidade e como a política urbana e ambiental municipal têm catalisado processos de injustiça socioambiental. Constata-se que o planejamento e a gestão se limitam a acompanhar as tendências sinalizadas pelo mercado imobiliário e que pressionam os ecossistemas, principalmente na porção sul do município, e também que os arranjos democráticos são forjados para inviabilizar a atuação da sociedade na defesa dos ecossistemas.

\section{Palavras-chave: Política Urbana. Política Ambiental. Espraiamento Urbano. Mudanças Climáticas.}

\section{INTRODUCTION}

The Anthropic action on ecosystems has advanced at an astounding rate since the Industrial Revolution, creating the geological era of Anthropocene (CRUTZEN, 2006, p.14), from processes of socioeconomic production that result in global warming. The new forms of global socioeconomic organization, represented by urban population growth, mobility and unbridled consumption, imply the intensive use of natural resources (BAl et.al, 2016), amplifying, in a vicious circle, the causes and impacts of changes from global to local scale.

In the surroundings of cities, deforestation is the main indicator of anthropogenic pressure on ecosystems. The horizontal urban expansion, as the maximum transformation of the local scale, has not only suppressed forests, but also pressured rivers and modified the soil.

Cities exist and have existed in history because men have found more advantageous and efficient ways to manage their social, economic and power relations in a spatially concentrated manner (CAMAGNI, 2005 , p. 21). In the course of history, as Santos (1997) reports, the relations of economic production and social reproduction that support capitalism situated, in the urban structure, in a different way, in time and in the territories under specific technical and political conditions, ways of obtaining profit through advantages provided by the concentration of people and things.

Thus, the locational advantage of the urban structure placed in the background, ironically, in the urban planning, the socially elaborated anthropological needs in the city; to live in the city, neglecting ecosystems.

According to Lefebvre (2001), the need for the meeting, the organization of work, the game, communication, and a quality of life were forged by technocratic urbanism and sales promoters, materialized in collective, commercial and real estate products that fragmented the city, generating spatial segregation and "new" urban problems, such as those of an environmental nature: water scarcity, natural disasters, heat waves are examples of these problems.

In their efforts to optimize the organization of economic activities and social reproduction and to minimize the socio-environmental chaos, generated and arising from past plans, supranational entities, multilateral agencies and the government have idealized diverse agendas and plans, whose guidelines and goals aim to achieve "urban sustainability" (LEFF, 2007). At first sight, the paradigm break brings important reflections on the political strength of local urban agents in decision-making processes and inevitable concerns about the overload of urban society on planet Earth.

However, it is urgent to point out the contradictions that exist in the interface of urban and environmental planning, that catalyze the evolution of land use and occupation conflicts, which in turn accentuate environmental problems. And, mainly, to highlight the appropriation and instrumentalization of the discourse of environmental protection for real estate speculation purposes.

When the Theory of Value from Adam Smith (1776 [1996]) denies the priority of agricultural production in generating wealth, nature is purposefully pointed out as an obstacle to economic development in 
classical economic theories, who attributed to work a fundamental role in the generation of wealth ${ }^{1}$. Neil Smith (1988), reflecting on the complex process of production of nature under the capitalist logic of space production, highlights that the devaluation of nature in theory was accompanied by its devaluation in reality for its appropriation as a means of production.

In the course of urbanization, here understood as a multi-dimensional process catalyzed by industrialization, the supposed domination of nature was convenient in theory and in practice until the crisis of scarcity of resources or its most immediate effects (SMITH, 1988), such as climate change. Floods, landslides, different kinds of pollutions and other pressures on ecosystems are some of the most immediate and perceived effects on the scale of the city. They result from planning oriented to market trends and real estate speculation. In other words, they are not the result of an environmental crisis, but of the contradiction of the urban space production process itself, which expresses its development limits by assigning value to natural resources such as water, vegetation and fertile soil.

A claim of nature is being materialized in government policies, plans, programs and projects. It is an indirect advertisement to escape not only the tendency of a deteriorated, fragmented and dispersed city but, above all, as argued by Leff (2007, p.67), it is an appeal to "the construction of another productive rationality, founded on the potentials of nature". The adoption of this perspective would demand a readjustment of the planning, of the guidelines of the territorial ordering and of the forms of regulation of the public spaces and the environmental protection areas in the city, but, above all, a readjustment in the forms and spectrum of the urban governance (SOUZA, 2001).

The decentralization of administrative competences and the participation of society in urban planning have been pointed out as democratic ways capable of mitigating socio-environmental problems (UN, 2016; JACOBI \& SULAIMAN, 2016). However, this overestimation of local power in decision-making processes, as an instigator of social justice and environmental protection, contained in international guidelines, only works when citizens truly contribute to the implementation and, mainly, to the monitoring of public policies. Otherwise, as Souza (2001) argues, there is a risk of instrumentalizing the discourse of popular participation in planning and environmental protection to forge interests of capital productivity over urban space, unfortunately, as argued by Campbell (1996, p.196).

Controls over land use and urban development in Third World cities have been weak, and most of the instruments and techniques adopted in developed countries - land use planning and master plans, zoning, permits to use of land and to build, in addition to the territorial tax - it is emasculated in developing countries by the power of demand, administration difficulties, special interests and corruption (CAMPBELL, 1992, p.196).

In this regard, this article aims to present, from the recent deforestation in the municipality of João Pessoa, the main areas of urban expansion and their legal and socio-environmental characteristics to discuss how urban and environmental municipal policy have subsidized the process of urban expansion at the expense of environmental preservation .

\subsection{URBAN SPREADING VERSUS SUSTAINABLE URBANISM}

More than $50 \%$ of the world's population lives in urban areas that occupy less than $1 \%$ of the earth's surface (IPCC, 2019). In addition to increasing Greenhouse gas emissions (GHG), motorized transport, civil construction, energy expenditure in maintaining and operating cities (SCHAEFFERA et. Al, 2012; BORBA, 2012), the world's urban population generates about $25 \%$ of the total global emissions of carbon, through the use of energy (IPCC, 2014).

The pressure of urbanization on ecosystems and the degradation of forested areas, inside and outside the urban environment, tend to increase, either due to the need for housing production or the consumption of food and other goods, mostly produced miles away from large cities. 
Among the main impacts of climate change in Brazil are the increase in temperature, the change in the rainfall regime and the increase in the occurrence of extreme weather, with special emphasis on rainy extremes, increased occurrence of droughts, in addition to elevation of the sea level (MARENGO, 2014).

Disorganized and exploited by the desire for immediate profit urbanization (HARVEY, 2001) has consequences in increasing the climatic risk to the population. In the rainy extremes, the lack of urban infrastructure such as rainwater drainage and environmental sanitation, as well as occupation of floodplains and slopes, intensify the impact of rains in urban areas (TUCCI, 2008), mainly, but not exclusively, in precarious settlements, where the poorest and most vulnerable population resides to the impacts of these events (HARDOY \& PANDIELLA 2009).

The Assessment Report 5 (AR5) from IPCC (2014) points out that the most socioeconomically vulnerable populations are also the most vulnerable to the impacts of climate change: the intrinsic relations of income, social class, gender, ethnicity, age and special needs are conditioning factors of adaptive capacity and risk exposure.

If socioeconomic vulnerability is one of the main conditioning factors of the intensity of the impact of climate change on populations (OJIMA, 2009; BARCELLOS AND HACON, 2007), the processes to reduce the impacts of climate change in cities pass, necessarily, to new perspectives of governance, based on the democratic and participatory processes laid down by the legislation (JACOBI and SULAIMAN, 2016), on the popular knowledge of traditional communities and also on the reduction of socioeconomic inequality.

The reduction of social inequality is a priority issue for the adaptation of the Brazilian population to the impacts of climate change. The IPCC (2014) emphasizes the importance of income transfer policies, including mention of the Bolsa Família program in AR5. In Brazil, 75\% of the 5,570 municipalities are exempt from elaborating Master Plans because they have less than 20 thousand inhabitants.

Despite the Statute of the City (2001) and Reurb (2017) establishing essential legal instruments to improve the quality of urban infrastructure, especially in precarious or informal settlements, the low institutional capacity of many Brazilian municipalities (ALMEIDA et al, 2017), linked to the pressures of power of capital over urban dynamics make the application of such instruments difficult. These facts compromise urban development and, consequently, sustainable urban planning. The vulnerability is also intensified due to the difficulty in organizing preventive actions of the civil defense, which still acts in the relief and not in the prevention ${ }^{2}$ (NOGUEIRA E CANIL, 2018).

If it is essential to promote sustainable urban planning as adaptation to climate change, to encourage urban agriculture, afforestation and the permeability of cities, as well as to promote the suitable densification of cities, inhibiting the spreading and, consequently, the reduction of pressure from urban areas on ecosystems and rural areas, smart urban density and the implementation of green and digitalized infrastructures are elements of urban development that favor non-polluting mobility with lower energy expenditure (COHEN, 2017).

For Nakano (2018), are the well applied urban instruments that can determine the "optimal density point", from a socio-environmental perspective. In this sense, the municipality of João Pessoa is in the opposite direction of promoting a city adapted to the climate crisis, accommodating urban sprawl, especially over the last Atlantic Forest reserves and water supply courses in the municipality, so important for mitigating the impacts of climate change in the occurrence of diseases, heat waves, in water security, in addition to disasters related to occupations on the banks of rivers. 


\subsection{URBAN SPRAWL IN JOÃO PESSOA}

João Pessoa, capital of the State of Paraíba, Northeast Brazil, has approximately 800,000 inhabitants, with $214 \mathrm{~km}^{2}, 64$ neighborhoods and 120 subnormal agglomerations (IBGE, 2010). Only 20\% of the population has completed higher education and $15 \%$ of the population is between poor and extremely poor, with an income below 1 minimum wage (IBGE, 2010).

In the municipality of João Pessoa, there are four Conservation Units, registered in the National System of Conservation Units (SNUC), namely the National Forest Restinga de Cabedelo - FLONA (2004), the "Parque Nacional Cuiá" (Municipal Natural Park) (2012), "Reserva da Vida Silvestre Mata do Buraquinho" (Remnant of Atlantic Forest) (2014) and "the Parque Estadual das Trilhas" (State Park) (2017), as shown in Figure 1.

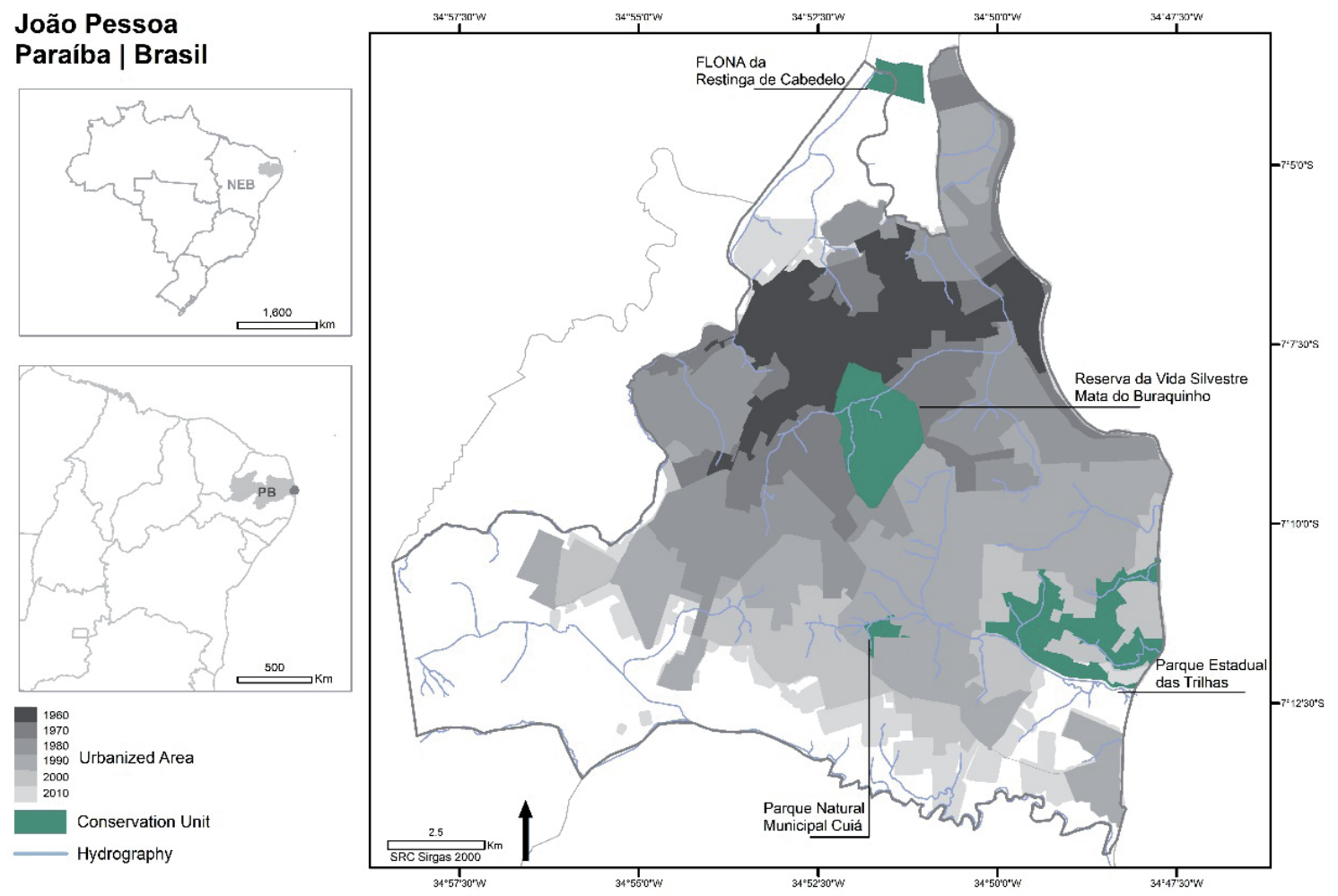

Figure 1 | Location map of João Pessoa: protected areas, green areas and urbanized area.

Source: MMA, 2019; IBGE, 2010. Elaborated by the authors.

The 1960s is a milestone in the urban expansion of the city, fostered by private initiative, with the consonance and intervention of the public authorities. The development of motorized and private transport allowed access to more distant places from the central area, which added to the opening of important avenues such as Epitácio Pessoa and Pedro II, and the transposition of the courses of the city's rivers, especially the Jaguaribe, Mandacaru, Tambiá and small tributaries, enabled the growth of the urban structure for the north-northeast region (SILVEIRA et al., 2015).

Currently, this logic of production of urban space is guided by the logic of the real estate market which directs the growth of the urban structure to the southern part of the city, where there is no consolidated urban infrastructure and remnants of the Atlantic Forest are systematically suppressed to allocate, mainly, tourist enterprises of the municipal and state governments, and vertical residential real estate products, for a low income in the south-southwest portion, and for high income in the south-southeast portion of the municipality, constituting a fragmented city (HARVEY, 2001). 


\section{METHODOLOGY}

Spatial and socio-environmental data were used and correlated in spatial analysis techniques for building maps that allowed us to outline the reality of urban expansion. The survey of the legal provisions that regulate the use and occupation of the city's land, as well as the democratic records of hearings and municipal councils served to identify and characterize the dynamics and political arrangements existing in the city.

To understand the issue, an alignment of the urban and environmental debate was sought by selecting a conceptual repertoire capable of providing an understanding of the social nature of the city and the ecological processes that occur in urban structures.

The concepts were divided into three main types: a) those indispensable for thinking about the problem, such as "space production" and "climate change"; b) those that are in the acceptance phase within the scope of the philosophical validation system that use the former, although necessary, as "sustainability"; c) and those that are not recurring, but that in this work were fundamental to align the dimensions of analysis, such as the "scales policy".

In this sense, the bibliographic survey consisted of the search for classic works, theoretical reviews and the state of the art via official documents (minutes, plans, maps and reports) and legal provisions, which in turn indicated the socio-economic and spatial data indispensable to spatial analysis.

The geostatistics were elaborated from data derived from the Global Forest Change project (HANSEN et al., 2013), data from IBGE (2010, 2017), from the Municipal Master Plan (Law 054/2009) and Ministry of the Environment (2019), in a georeferenced information system.

Deforestation data (HANSEN et al., 2013) in raster format indicate the date of forest loss each year, in a historical series from 2000 to 2018, based on Landsat images. These data were vectorized and later transformed into patches of concentration of occurrence of vegetation loss, based on the density of lines of each vector.

These patches of concentration of occurrence of vegetation loss indicated, in mesoscale, which areas are most affected by deforestation, since the aim is to observe the production process of urban space, from the point of view of the loss of green areas and pressure on ecosystems.

Understanding that deforestation occurs through urban expansion over ecosystems, vegetation loss spots were plotted on Conservation Units and hydrography. On the other hand, to understand the socio-environmental characteristics of urban sprawl, these spots were also plotted on the classification of IBGE's Intra-urban Typologies (2017), which points, from data on environmental sanitation, income, education, access to goods and services, the living conditions of the population.

On a more detailed scale, maps of vegetation loss patches were plotted with Macrozoning, so that it was possible to observe the production of urban space based on the urban governance strategies of the law in force. Finally, in conjunction with these cartograms, images from the Google Earth platform were added, allowing the observation of anthropic actions that cause deforestation.

From the generated cartograms, analyzes of the production of the urban space were made, observing the different socio-environmental and legal aspects of the urban expansion of the municipality of João Pessoa.

\section{RESULTS AND DISCUSSION}

The first Master Plan of João Pessoa was prepared in 1992 and officially published in 1994, through Complementary Law 03/1994 (PMJP, 1994). It is the result of the Brazilian urban reform, but it does not represent the first territorial ordering and zoning of the municipality. However, as a basic 
instrument of Brazilian urban policy, it presented guidelines, rules and restrictions for the use and occupation of the city's land. The plan's possible urban expansion design, as shown in Figure 2, describes the environmental impacts by marking it as permanent protection areas and as municipal and state conservation units.
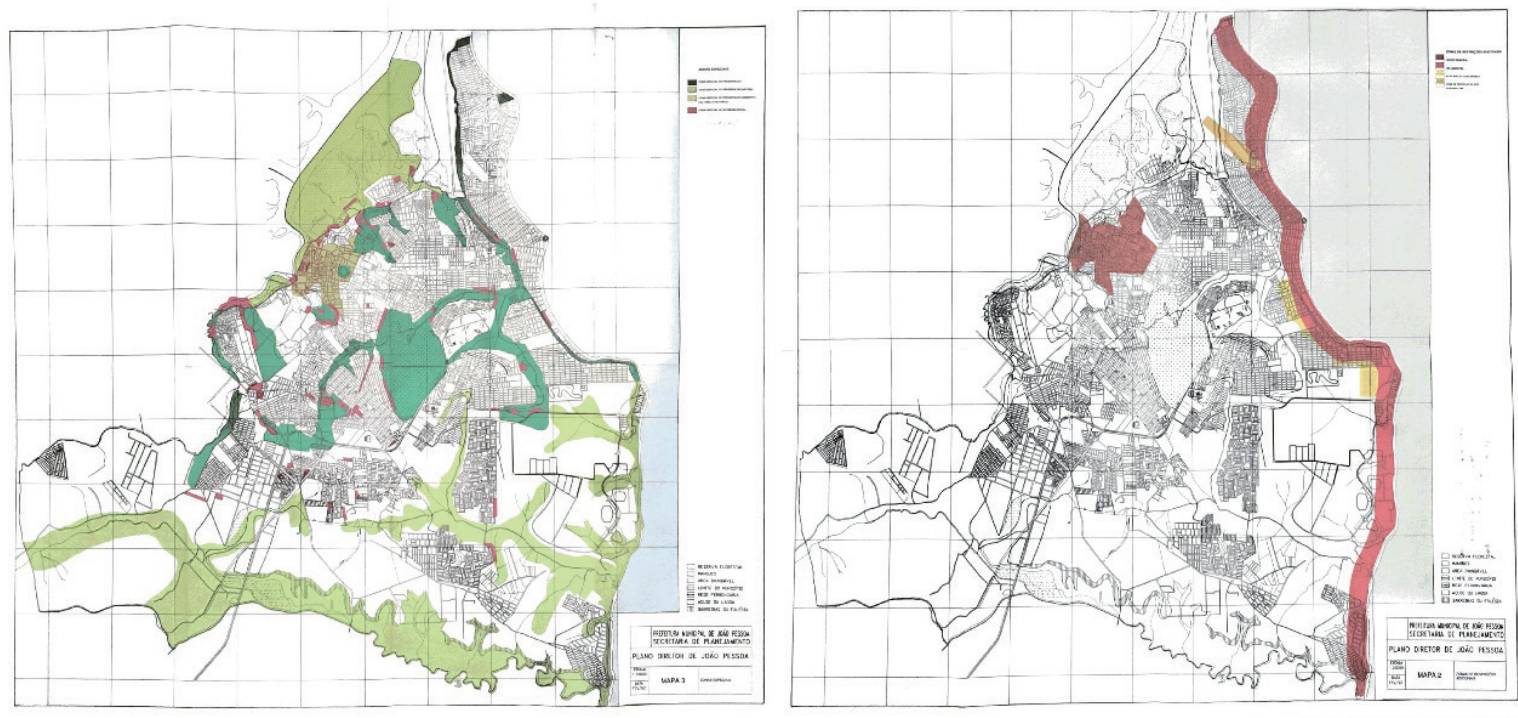

Figure 2 | Master Plan of João Pessoa, 1992.

Source: Scanned from analogical originals.

When analyzing past zoning and the recent use and occupation of the soil, it is possible to verify an undisguised political-ideological content in its elaboration, by promoting land stock for tourist real estate enterprises in the coastal strip of the city (HARVEY, 2001, p. 166-170 and p. 221). The zones of additional restrictions, outlined in Figure 3, and characterized as areas of "social interest for the preservation of environmental, landscape, historical and cultural characteristics" were gradually being neglected in the name of private interests and sanctioned by city governments on behalf of "urban development", contradicting Leff's (2007) expectations that interinstitutional arrangements and legal instruments could direct urban policy towards sustainability.

The inexistence of a Brazilian urban planning system articulated with the legal provisions that sanction the urban parameters of land use and occupation with other public policies that affect the urban, such as the environmental, allows maneuvers based on less visible speculative interests to be performed without adequate supervision or control by the government.

For example, the construction in progress of a hypermarket, whose architectural project highlights the construction of $12,000 \mathrm{~m}^{2}$ in the Environmental Amenization Sector (SAA) and the Permanent Preservation Area (APP). The environmental installation license was granted by the Municipal Environment Secretariat and unanimously canceled by the Municipal Environment Council (COMAM).

The opinion of the counselor of the Federal University of Paraíba, to case no 2018/068932 and 2018/066994 of the Secretariat of the Environment, was unequivocal in pointing out several aspects by which the work should be interrupted, among them: i) the incongruity in the typification of the enterprise between the Planning Secretariat (SEPLAN) and SEMAM; ii) the negligence of the body responsible for issuing the environmental license when allowing a lot occupancy rate double of that stipulated by law in the environmental softening sector; iii) by not preventing vegetation removal of fragments from the Atlantic Forest; iv) authorize the installation of a project that does not have a solid waste and effluent management plan, in an area without sanitation infrastructure; v) and do not present a neighborhood impact study for a project of this size. Despite the unanimous request for revocation of the license, the work continues in progress. 
This fact is a clear example of how the production of urban space takes place in accordance with the interests of capital above the socio-environmental interests of the population, based on the consent and convenience of the public authorities.

These practices of municipal administrations not only demonstrate an imbalance between the scales policy of urban legislation and environmental legislation, which allows a non-compliance between one and the other, according to the interest of the agents who participate and operate the bureaucratic ritual, according to Campbell (1992).

The natural processes and flows that take place in the urban landscape are fundamental for a quality of everyday life in the city. It is not just a matter of environmental protection, but a right to the city. Contact with nature, sunbathing, breathing fresh air, walking to shop, having access to drinking water, meeting friends and working are individual needs that we collectively carry out in the city.

With the institutional setbacks in critical areas such as the environmental and the urban, the advance of the urban structure in the fragments of the Atlantic Forest has been allowed, not only in the municipality of João Pessoa, but also as it occurs in the north coast of the State of São Paulo ( BORELLI, 2007), with the advance of fragmented urbanization, based on the tourist exploration of the region and which implies the loss of life quality in the city, or according to Barreto (2013), who has deeply studied the history of the occupation of the Northeast Atlantic Forest, since colonization to the present day.

Barreto (2013) also points out the need to promote connectivity between fragments of the Atlantic Forest in Northeast Brazil, a proposition that becomes unfeasible with urban sprawl and pressure on what remains of this biome. Despite having two large non-urbanized areas, one to the north and one to the south, the deforestation of the municipality of João Pessoa is concentrated in the southern portion of the municipality, as shown in Figure 3, where there are quilombola, indigenous and artisanal fishermen communities, such as Paratibe, Tabajaras and Jacarapé, none of them demarcated or regulated.

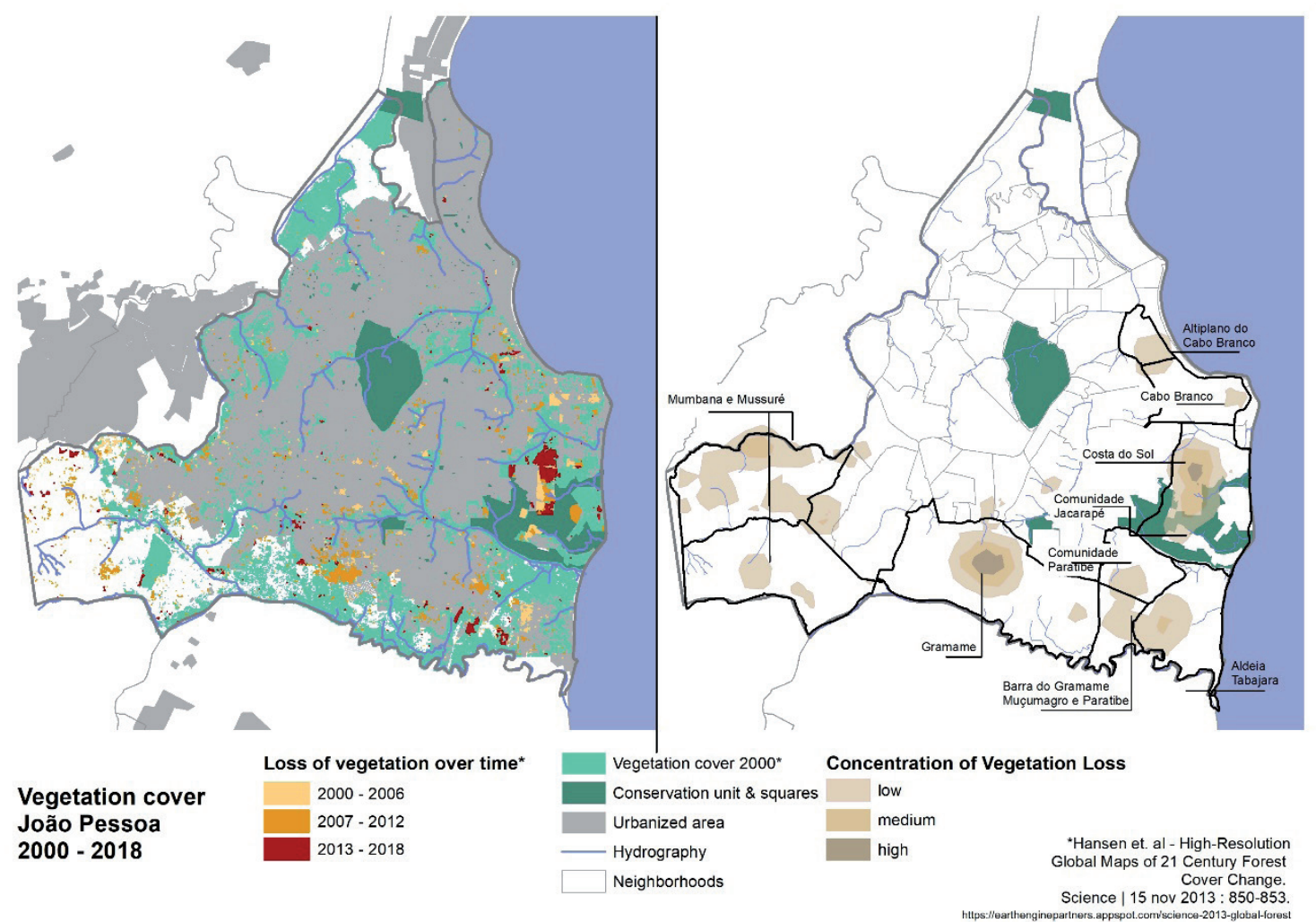

Figure 3 | Maps of vegetation cover and loss of vegetation in João Pessoa.

Source: Hansen et al. (2013), MMA (2019). Prepared by the authors. 
Between 2007 and 2018, large areas of deforestation can be seen in the southeastern portion, close to "Parque Estadual das Trilhas", a Conservation Unit enacted in 2017. The orange spot, in Figure 3, further east, is the Convention Center, inaugurated in 2012, and that is part of the development plan for a high standard tourism industrial district (GOVERNO DO ESTADO DA PARAÍBA, 2017).

In the northern portion of "Parque Estadual das Trilhas", Costa do Sol neighborhood, Figure 4, the most recent deforestation can be observed under the logic of capital that spatially follows the entrepreneurship of urban public policy (HARVEY, 2001,) to occupy areas previously forested and that now have transportation infrastructure brought by the installation of the Convention Center. In the southeastern portion, in neighborhoods such as Barra do Gramame, Muçumagro and Paratibe, deforestation appears towards the neighboring municipality, Conde, which has beaches disputed by the tourism sector.

The patches of loss of vegetation in the central south and southwest areas, respectively in the Gramame neighborhood, followed by the Mussure and Mumbaba neighborhoods, present themselves as the great frontier of expansion over ecosystems - from the Atlantic Forest areas to the Gramame River, which supplies the City. In Figure 4, it is possible to observe that, unlike the surroundings of "Parque Estadual das Trilhas", in these areas there is a low living condition (IBGE, 2017).

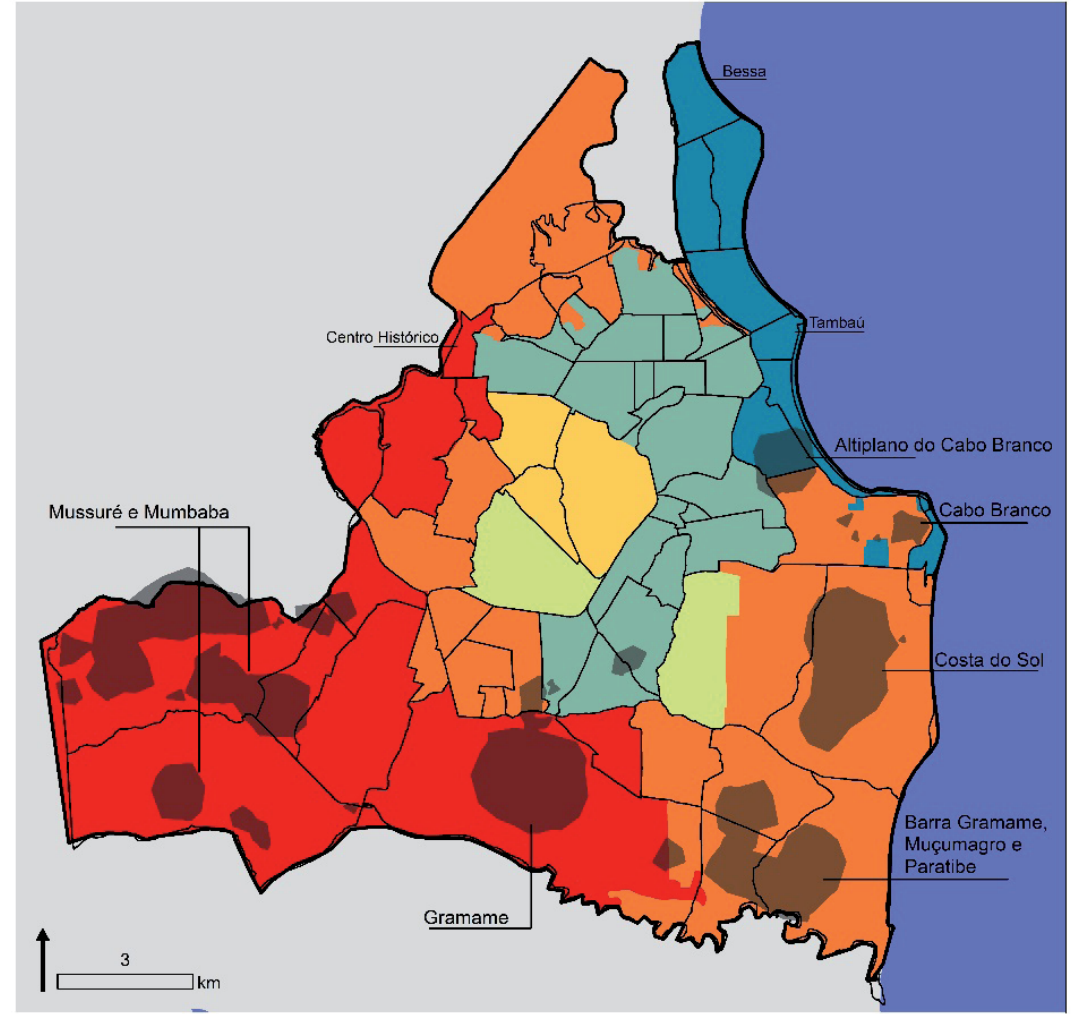

Figure 4 | Intra-urban typologies of João Pessoa.

Source: IBGE, 2017. Prepared by the authors.

\section{Living conditions of the population | BGE}

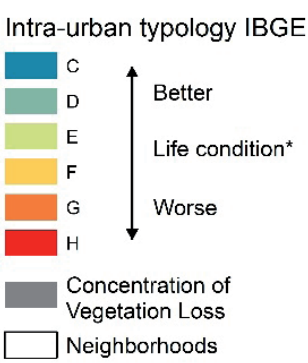

*Classification based on 2010 census data, based on income, environmental sanitation, access to goods and services and housing conditions, IBGE, 2017

With the calculation of the loss of vegetation, between 2012 and 2018, by macro-zone of the Master Plan, it is possible to observe that urban expansion occurs primarily (almost $90 \%$ of the total) over NonDense Areas, of Non-Priority Density, Environmental Amenization Sectors, Landscape Preservation and extremely close to the Environmental Protection Zones, often occurring on the margins of permanent preservation areas.

This finding points to a failure to comply with legislation and to the fragility of the municipal urban and environmental policy in the face of ecosystems, which should be valued in a city seen as touristic. 
Table 1 | Loss of vegetation (2012-2018) by Macro-zone of the Master Plan

\begin{tabular}{|c|c|c|}
\hline Macro-zone & Area (ha) & Percentual (\%) \\
\hline ENVIRONMENTAL PRESERVATION AREA - ZPA & 157.1 & 53.1 \\
\hline NON-DENSIFIED AREA - ZNA & 105.3 & 35.6 \\
\hline WITHOUT ZONING & 15.7 & 5.3 \\
\hline NON-PRIORITARY DENSIFIED AREA - ZANP & 12 & 4.1 \\
\hline LANDSCAPE PROTECTION SECTOR - SPP & 2.7 & 0.9 \\
\hline MINERAL EXPLORATION SECTOR & 1.3 & 0.4 \\
\hline PRIORITARY DENSIFIED AREA - ZAP & 1 & 0.3 \\
\hline ENVIRONMENTAL MITIGATION SECTOR - SAA & 0.5 & 0.2 \\
\hline DEPOSITION AND TREATMENT OF LIQUID WASTE SECTOR & 0.3 & 0.1 \\
\hline
\end{tabular}

Source: Prepared by the authors based on data of Hansen et al., 2013 and PMJP.

In the southwestern portion of João Pessoa there are large patches of deforestation resulting from two very different processes: mining and social and popular housing, as shown in Figure 5.

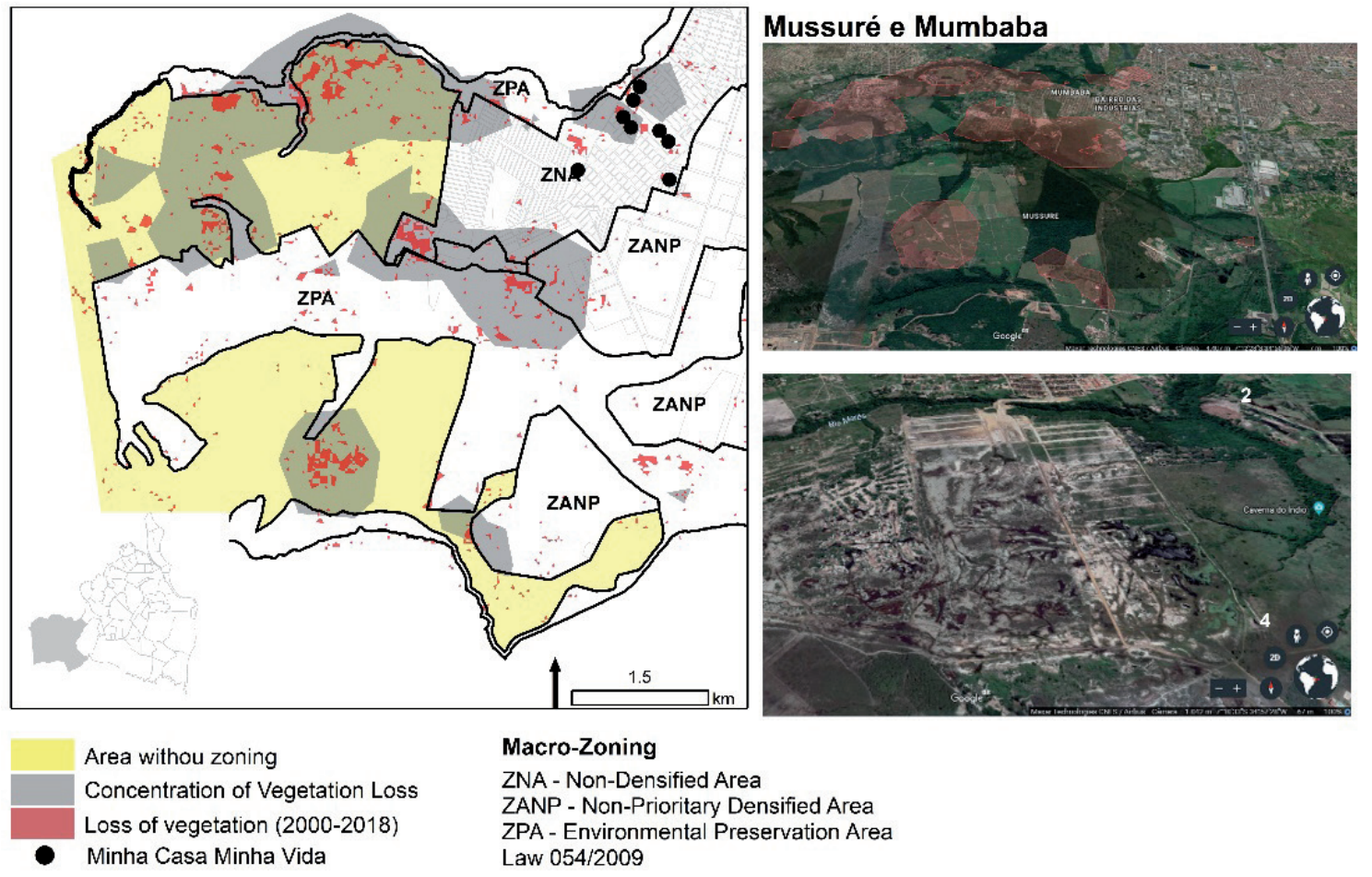

Figure $\mathbf{5}$ | Detail of the loss of vegetation in the Costa do Sol neighborhood. Source: Hansen et al. (2013), Law 054/2009, Google Earth Pro. Prepared by the authors.

In an area that does not have a macro-zone defined by the current law, mineral exploration (Figure 5) is perceived in the vicinity of Environmental Protection Zones.

According to Silva et al. (2016), urban expansion segregates the poorest from socio-environmental opportunities, since access to the city is through consumption and cost of land. In João Pessoa, and in other cities on the northeastern coast, the most distant areas from the "sea view" are the most excluded and Donegan (2019) has already discussed how the coastal urban infrastructure has an urban morphology that excludes the poorest portion of the population. 
In the Cabo Branco and Altiplano do Cabo Branco neighborhoods, although the deforestation patches are smaller (Figure 3), it is important to observe the high living conditions (IBGE, 2017) of the population in these areas (Figure 4) in order to understand how the capitalist production of urban space occurs in the most tourist regions of João Pessoa.

In the Costa do Sol neighborhood it is possible to observe (Figure 6) that, according to the current legislation (MPJP Municipal Law 054/2009), the loss of vegetation occurred in non-densified or non-priority areas. These are subdivisions approved from the first decade of this century, with horizontal condominiums that, despite being identified by the 2010 IBGE census as low-income, are now being occupied by upper middle class population, an assumption that can only be confirmed in the IBGE 2021 census.

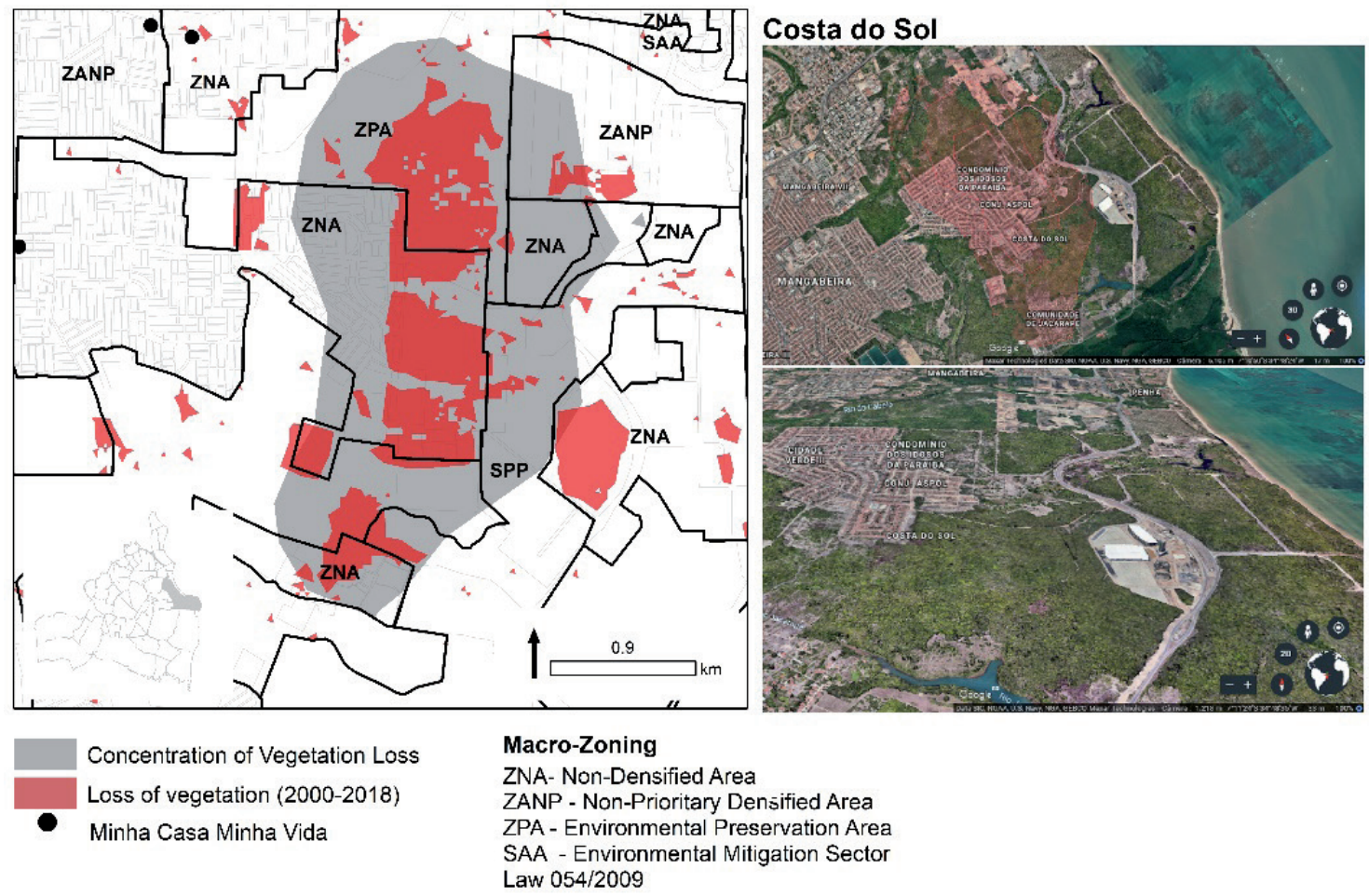

Figure 6 | Details of the loss of vegetation in the Costa do Sol neighborhood.

Source: Hansen et al. (2013), Law 054/2009, Google Earth Pro. Prepared by the authors.

The neighborhoods highlighted in Figure 6 follow the logic of segregation pointed out by Harvey (2001), in which a public-private partnership, not legalized, but agreed, serves urban infrastructure that does not exist outside the walls of closed condominiums, or that exists only in the vicinity of the high ones vertical condominiums, meeting the desires of the wealthiest class of the population.

The Convention Center, in the satellite image at the bottom of Figure 6, shows that the road infrastructure brought by the construction of the equipment contributes to the advancement of the urban spot in the southern region of João Pessoa. In the same image, the easternmost portion of the same photo shows a large forested area that will eventually become the high standard tourism industrial district (Government of the State of Paraíba, 2017), as shown in Figure 7 below. 


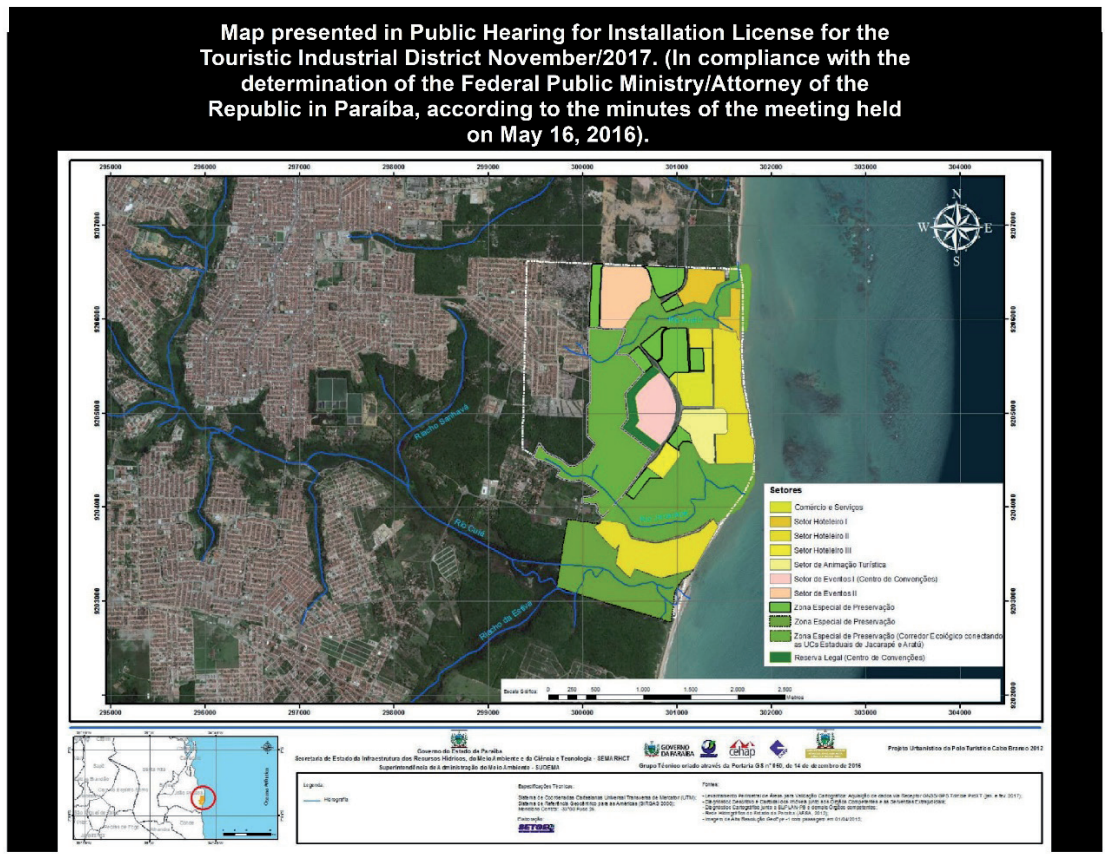

Figure 7 | Map of the urban development project for the Industrial Tourism District of João Pessoa.

Source: Paraiba State Government (2017).

It is in this same area that the Jacarapé Community is located, where artisanal fishermen live divided into two nuclei, one of which is by the waterfront (Figure 3). This community has undergone several removal attempts, to give way to tourist developments, materializing what the IPCC (2019) points out as land dispute and loss of livelihoods and subsistence of traditional communities.

The polygons of the conservation units surround the area of the tourist district forming a protective shield. The urban infrastructure destined to the tourist offer tends to have more burdens and to pressure the adjacent biodiversity more than the domestic demand. Ironically, much of the Atlantic Forest fragment that constitutes the main asset of the project will be removed to make room for the resorts that will be implemented. The economic and political rationality that guide these government projects and actions show an order based on market law, in which state entities act as urban entrepreneurs to attract investments (Harvey, 2001).

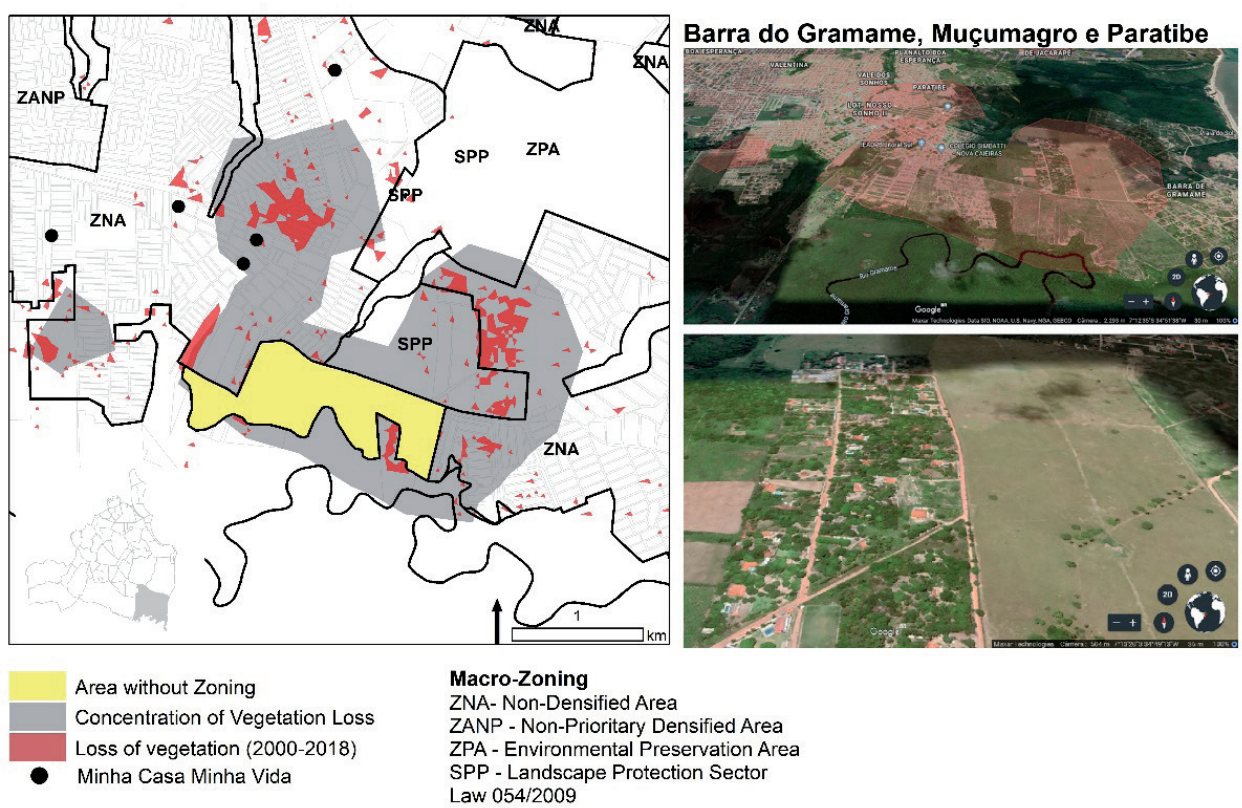

Figure 8 | Detail of the loss of vegetation in the neighborhoods Barra do Gramame, Muçumagro and Paratibe. Source: Hansen et al. (2013), Law 054/2009, Google Earth Pro. Prepared by the authors. 
In the southeastern portion of the municipality, deforestation is mainly due to the occupation of summer farms, as shown in Figure 8. Corroborating with Municipal Macrozoning, these are low-occupancy subdivisions. These settlements put pressure on the Gramame River and on traditional populations that are still struggling for recognition, such as the Paratibe community and the Tabajara indigenous people (QUARESMA, 2017), who must be evicted due to real estate speculation, the Paratibe community is threatened by the same removal logic of the Jacarapé community, also implying the loss of cultural ecosystem services, in addition to provision (IPCC, 2019).
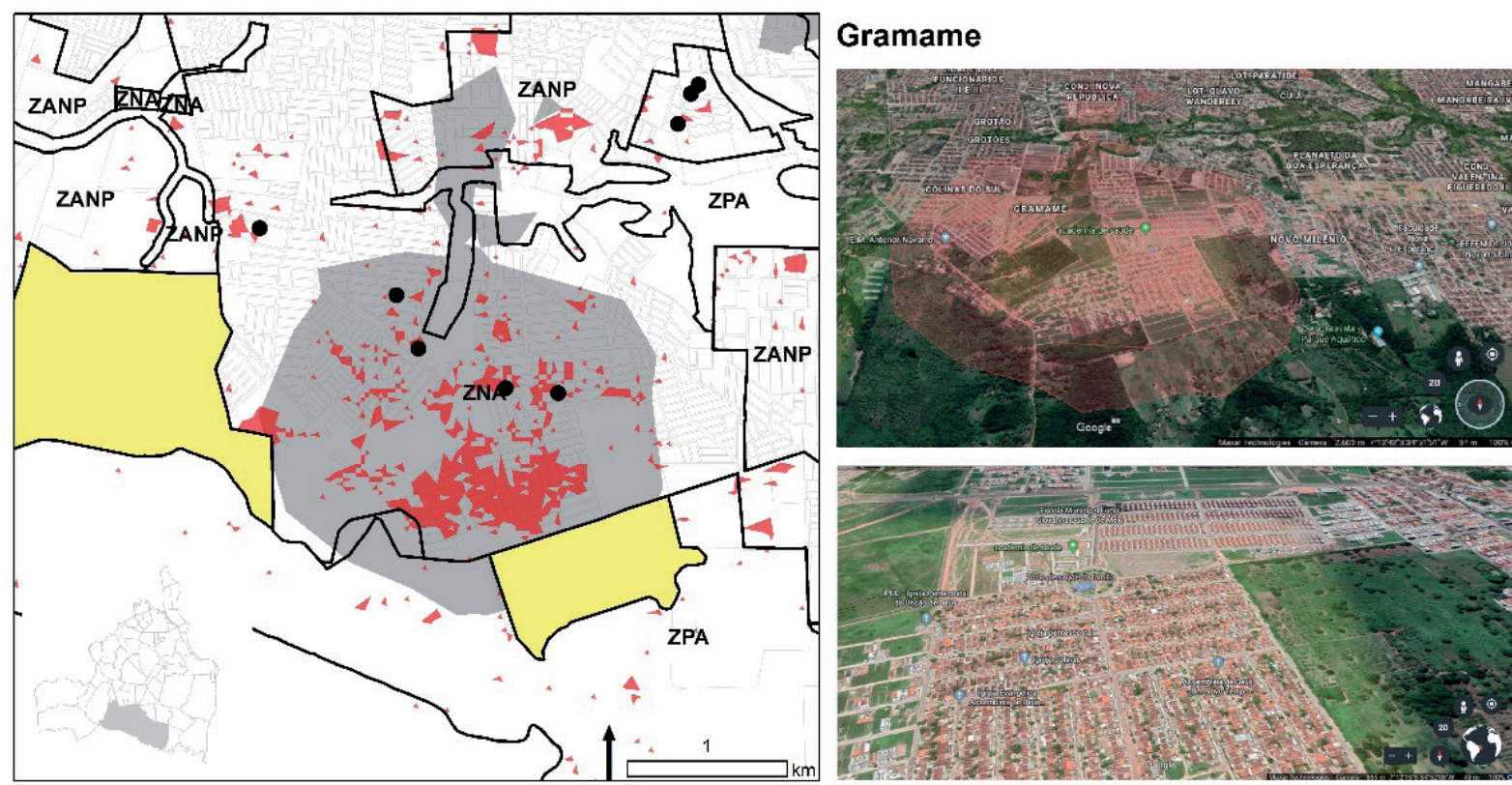

Area without Zoning Concentration of Vegetation Loss Loss of vegetation (2000-2018) Minha Casa Minha Vida

\section{Macro-Zoning}

ZNA- Non-Densified Area

ZANP - Non-Prioritary Densified Area

ZPA - Environmental Preservation Area

Law 054/2009

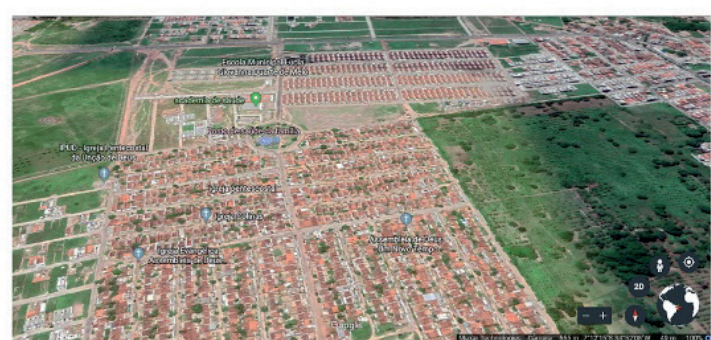

Figure 9 | Detail of the loss of vegetation in the Gramame neighborhood.

Source: Hansen et al. (2013), Law 054/2009, Google Earth Pro. Prepared by the authors.

In Gramame, the major vector of deforestation is the construction of low-income subdivisions, some subsidized by the Federal Government, with resources from the Minha Casa Minha Vida Program and others raised by small construction companies in the city. Despite being on a Non-Dense Area, the patch of loss of vegetation shows dense and continuous soil parceling.

They are small lots, with a high occupancy rate, as shown by the satellite images in Figure 10. Still on Figures 7 and 8, it is worth mentioning that the neighborhoods presented are very close to the Gramame River, a water course that supplies $70 \%$ of the city, which may (i) compromise the region's water availability in future scenarios of changes in rainfall regimes and (ii) put at risk of inundation or flooding the poor populations living near the river, with an increase in rainy extremes coupled with low infrastructure of environmental sanitation (HARDOY AND PANDIELLA, 2009). 

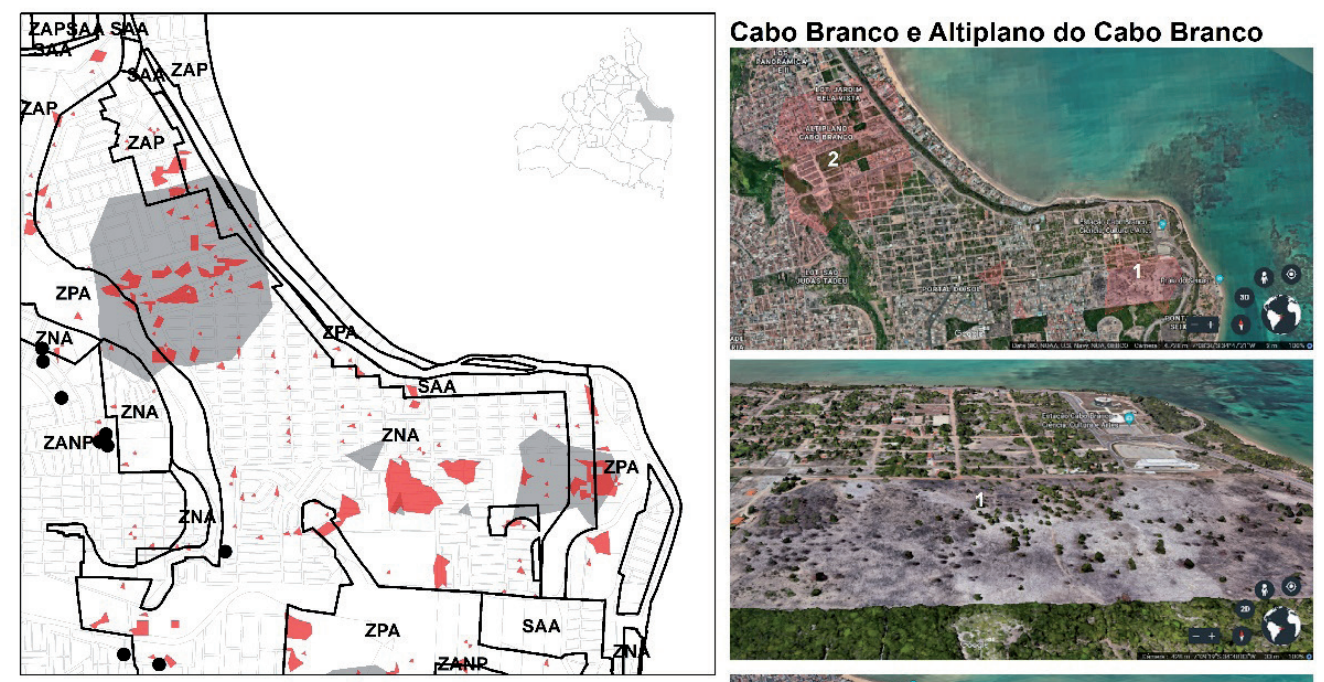

\footnotetext{
Concentration of Vegetation Loss

Loss of vegetation $(2000-2018)$

- Minha Casa Minha Vida

Macro-Zoning

ZNA- Non-Densified Area

ZANP - Non-Prioritary Densified Area

ZPA - Environmental Preservation Are

SAA - Environmental Mitigation Sector
} Law 054/2009
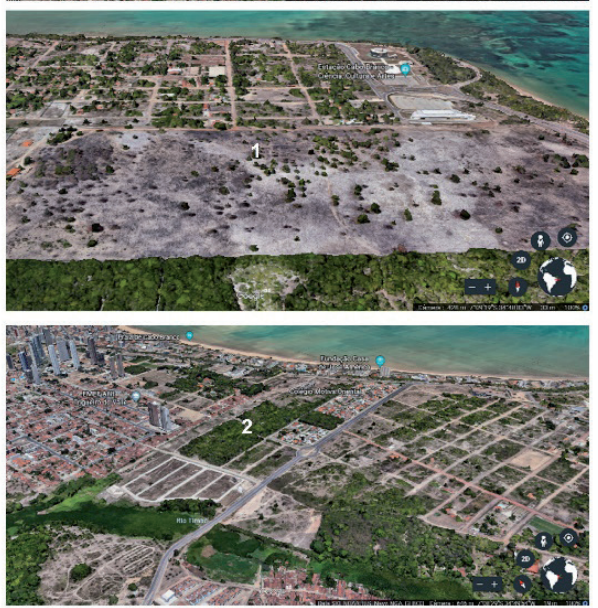

Figure 10 | Detail of vegetation loss in the Altiplano do Cabo Branco and Cabo Branco neighborhoods. Source: Hansen et al. (2013), Law 054/2009, Google Earth Pro. Prepared by the authors.

Located in a privileged location overlooking the sea, in the Cabo Branco and Altiplano do Cabo Branco neighborhoods, the region's deforestation occurred for the construction of horizontal high-income condominiums. In the Altiplano do Cabo Branco, Figure 10, satellite image in the middle, takes place around the extremely high-income vertical condominiums, approved by altering the template defined in the zoning, via decree, in 2008. In the Cabo Branco neighborhood are condominiums horizontal, also of very high income, with low occupancy rate. Both neighborhoods have low levels of environmental sanitation and the surrounding area does not have an urban drainage system (IBGE, 2010). These neighborhoods are located on the Barrier of Cabo Branco, of geological formation sensitive to landslides, located in the direction of the "Seixas" corals, which are threatened by the erosion of the cliff. For example, in June 2019, during a rainy extreme that lasted more than 72 hours, part of the barrier slid over the sea, affecting part of the corals. In this process of formalized occupation, legal from the point of view of urban policy, it subverts the idealization of a sustainable city of Leff (2007), strengthening the segregation of the elite in clusters of urban reality that does not exist outside the walls or perimeters of these neighborhoods.

The greatest losses of vegetated area occurred in a preservation area of the landscape, which is not densified, and in the area of the Master Plan that has no zoning whatsoever. This fact demonstrates that the establishment of laws to regulate the use and occupation of land does not align with the environmental policy, because, the reasonable flexibility existing within the scope of these regulatory devices opens space for the interests of the actors that compose the managements to redefine priorities in the name of urban entrepreneurship. Nevertheless, the popular participation forged within the ambit of the environment and urban development councils of the city of João Pessoa corroborates these advances that destroy the city's ecosystems.

In the context of climate change, land disputes within the power relations of capital tend to harm micro rural producers and traditional communities (IPCC, 2019) and may, in the near future, compromise the food security of the low-income population and traditional populations that persist in their rural subsistence characteristics, mainly in the southeastern portion of the municipality (Figure 3 ) where, as previously stated, riverside, indigenous and quilombola residents live. 
Furthermore, ecosystem services related to the city's climatic-environmental regulation (CARVALHO E SZLAFSZTEIN, 2019 and VIEIRA ET AL., 2018) can be compromised with the loss of the Atlantic Forest, bringing consequences for water security in the city, mainly due to anthropic pressure on the Gramame River (Figure 8), in addition to contributing to the increase of heat islands (OKE et al., 2017 pp. 197), in future climatic scenarios.

Finally, according to Figures 5, 8 and 9, a large part of the deforestation has occurred in areas of low urban infrastructure, with the implantation of subdivisions for low income (Figure 4), imposing risk to these communities, which can experience direct and indirect effects of climate change (IPCC, 2019), mainly those associated with disasters, such as inundations, floods and runoffs, as a result of the increase in the intensity and frequency of rainy extremes combined with the low quality of environmental sanitation services (TUCCl, 2008), contrary to indications from the National Adaptation Plan - PNA (MMA, 2016), to promote urbanization of precarious settlements, and maintenance of populations in their original settlements, in the consolidated portion of the city.

\section{FINAL CONSIDERATIONS}

The urban space production process per se press the ecosystems, the pace and urban lifestyle demand the degradation of natural resources and the conformation of urban structures in Brazil were based on deforestation, soil waterproofing, contamination of water bodies and in the occupation of vulnerable areas.

In the Anthropocene, with the reality of the climatic emergency, an environmental rationality based on the idea that everything and everyone is part of interconnected and interdependent systems and subsystems has guided the production of institutional reports, policies, plans and governmental urban programs, but, but, although the guidelines and goals are from the perspective of sustainability, in practice, the executive projects arising from these documents do not correspond to multifunctional solutions that mitigate urban environmental problems.

What is perceived is that, across governments, there is a mismatch between planning and management. It is a marketing and deregulation agenda, characterized by the misunderstanding of nature and its cycles, which appropriates from it to raise funds and "plan projects" of special and dubious interests.

The unsustainable urbanism, wide open on maps, is the result of the supposed "democratic management of the city", which grows and spreads according to profit and walls. With the consent of the public authorities for non-compliance with legislation, be it urban or environmental, the growth of the urban structure of the municipality of João Pessoa advances on important remnants of the Atlantic Forest.

This neglect of the public power is due both to the implementation of institutional projects for the settlement of low-income families, in areas lacking urban infrastructure, far from the commercial area and services of the city, as well as by the impetus for real estate and services aimed at elites and tourists with high purchasing power.

On the one hand, the vertical densification of areas already consolidated has been discarded by the upper social classes, who prefer the walls of closed horizontal condominiums or clusters of vertical condominiums, whose "view of nature" is the main asset of the projects; on the other, the provision of low-income housing, allocated in areas that are far from the city's tourist attractions, and demand the suppression of vegetation because they are close to the industrial and mining area, exposed to pollution and other risks associated with this proximity.

The adaptation of cities to the climate crisis involves sustainable densification, instead of urban sprawl, promoting the implementation of green infrastructure, sustainable transport and mobility: compact cities where internal mobility does not imply GHG emissions (MMA, 2016), and which can only be managed in a participatory manner, with socio-environmental justice for all inhabitants. 
Climate threats do not affect the entire population in the same way, the lower income populations have less resilience than the more affluent classes but, on the other hand, with the recurrence of hydrometeorological disasters that affect these low-income or traditional communities, such as riverside communities, improve adaptation techniques that need to be taken into account when planning and implementing adaptation actions.

Adaptive measures must necessarily include the implementation of environmental sanitation services to reduce the risk of extreme events and the proliferation of waterborne and vector-borne diseases, especially in serving populations with less financial resources. These services must also be linked to the way of life of traditional populations and the ecosystem in which they will be inserted, based on alternatives for the collection of domestic sewage treatment and rainwater management that do not involve large infrastructure and concrete works, which may represent new environmental impacts.

Regarding traditional peoples and communities, the PNA (MMA, 2016) points out the need to maintain these populations in their traditional environments, promoting land regularization and agroextractive tools.

Deforestation, in addition to promoting the loss of GHG absorption capacity, compromises ecosystem services (i) of environmental regulation - the loss of vegetation and soil impermeability is directly related to heat islands, maintenance of water courses and its water capacity, increased energy consumption for environmental comfort, (ii) provision - by expelling riverside communities and small rural producers, in addition to (iii) culturally compromising the way of life of these populations.

As a future suggestion, it would be necessary to analyze the living conditions of the populations of the deforested areas with updated census data in 2021, as well as with data on environmental licenses and building permits granted throughout the historical data series of Hansen et al. (2013), to understand the impacts of urban expansion in the city of João Pessoa.

\section{NOTES}

1 | The proposed reflection aims only to admit the naturalness of man and the historicity of nature, as discussing the conceptual dualism of the term is not the objective of this work.

2 | The Creation of Cemaden for risk monitoring and the creation of CENAD and the action structure of civil defenses in the three spheres of the federation are already important steps in the political, scientific and social organization of risk management actions in the country.

\section{REFERENCES}

ALMEIDA, G. M. et al. A política nacional de regularização fundiária: capacidades institucionais dos municípios na implementação do Programa Federal Papel Passado e suas implicações na gestão do território. In: XVII Encontro Nacional da Associação Nacional de Pós-Graduação e Pesquisa em Planejamento Urbano e Regional - Enanpur, XVII, 2017. São Paulo, 2017.

BAI, X. et al. Plausible and desirable futures in the Anthropocene: A new research agenda. Global Environmental Change, v. 39, p. 351-362, 2016. https://doi.org/10.1016/j.gloenvcha.2015.09.017

BARCELLOS, C.; HACON, S. Velhos indicadores para novos problemas: a relação entre saneamento e saúde. Revista Panamericana de Salud, SciELO Public Health, v. 22, n. 3, 2007.

BARRETO, Cristiane Gomes. Devastação e proteção da mata atlântica nordestina: formação da paisagem e políticas ambientais. 294 f., il. Tese (Doutorado em Desenvolvimento Sustentável) - Universidade de Brasília, 2013.

BORBA, B.S.M.C. et al. Energy-related climate change mitigation in Brazil: Potential, abatement costs and associated policies. Energy Policy, v. 49, p. 430-441, 2012. https://doi.org/10.1016/j.enpol.2012.06.040 
BORELLI, E. Urbanização e Qualidade Ambiental: o Processo de Produção do Espaço da Costa Brasileira. INTERthesis, v. 4, p. 1-27, Florianópolis, 2007. DOI: https://doi.org/10.5007/\%25x

CAMAGNI, R. Economía Urbana. Barcelona, Espanha: Antoni Bosch Editor, 2005.

CAMPBELL, T. Desenvolvimento urbano no Terceiro Mundo: dilemas ambientais e pobres urbanos. In: LEONARD, H. Jeffrey (org.): Meio ambiente e pobreza: Estratégias de desenvolvimento para uma agenda comum. Rio de Janeiro: Ed. Jorge Zahar, 2002.

CARVALHO, R.M.; SZLAFSZTEIN, C.F. Urban vegetation loss and ecosystem services: The influence on climate regulation and noise and air pollution. Environmental Pollution, n. 245, p. 844-852, 2019. DOI: doi.org/10.1016/j. envpol.2018.10.114

COHEN, D.A. Climate Justice and the Right to the City. USA: Penn University, 2018.

CRUTZEN, P.J. The Anthropocene. In: EHLERS E, KRAFF, T. (eds). Earth System Science in the Anthropocene. Berlin: Ed. Springer, 2006.

DONEGAN, L. Qual é a sua praia? Brasília: Ed. FRBH, 2019.

GOOGLE EARTH. Satellite images. Disponível em https://earth.google.com/web/ . Acesso em Janeiro de 2020.

GOVERNO DO ESTADO DA PARAÍBA. Audiência Pública para Licença de Instalação para o Distrito Industrial do Turismo. Em atendimento à determinação do Ministério Público Federal/Procuradoria da República na Paraíba, conforme Ata de Reunião realizada em 16 de maio de 2016.

HACON, SS.; OLIVEIRA, BFA; SILVEIRA, I. Capítulo 4: Health Sector. NOBRE, C.A.; MARENGO, J.A., SOARES, W.R. (Org.): Climate Change Risks in Brazil: A Review of the Health Sector Impacts of $4{ }^{\circ} \mathrm{C}$ or more Temperature Rise. Ed. Springer, 2018.

HANSEN et. al. High-Resolution Global Maps of 21 Century Forest Cover Change. Science, v. 342, i. 6160, p. 850853, 2013. DOI: 10.1126/science.1244693

HARDOY, J. AND PANDIELLA, G. Urban poverty and vulnerability to climate change in Latin America. Environment and Urbanization, v. 21, n. 1, p. 203-224, 2009. https://doi.org/10.1177/0956247809103019

HARVEY, D. A produção capitalista do espaço. São Paulo: Ed. Anna Blume, 2001.

IBGE. Censo demográfico 2010. Disponível em ibge.gov.br. Acesso em janeiro de 2020.

IBGE. Tipologias Intraurbanas. 2017. Disponível em ibge.gov.br. Acesso em janeiro de 2020.

IPCC. Climate Change 2014: Impacts, Adaptation, and Vulnerability. Contribution of Working Group II. Fifth Assessment Report of the IPCC. Cambridge, UK and New York, NY, USA: Cambridge University Press. 2014.

IPCC. Climate Change and Land Special Report. Cambridge, United Kingdom and New York, NY, USA: Cambridge University Press, 2019.

JACOBI, P., E SULAIMAN, S. Governança ambiental urbana em face das mudanças climáticas. Revista USP, v. 09, p.133-142, 2016. DOI: https://doi.org/10.11606/issn.2316-9036.v0i109p133-142

LEFEBVRE, H. O Direito à Cidade. São Paulo: Ed. Centauro, Reedição, 2011.

LEFF, E. Saber Ambiental: sustentabilidade, racionalidade, complexidade e poder. Petrópolis, RJ: Ed. Vozes, 2001.

MARENGO, J. O futuro do clima no Brasil. Revista USP, n. 103, p. 25-32. São Paulo. 2014. DOI: https://doi. org/10.11606/issn.2316-9036.v0i103p25-32

MINISTÉRIO DO MEIO AMBIENTE. Plano Nacional de Adaptação. Brasília, 2016. 
MOURA, A. K. C.; GARCIA, L. G. Políticas públicas de turismo e sustentabilidade: o polo turístico Cabo Branco em análise. CULTUR - Revista de Cultura e Turismo, Ano 03, n. 03, p. 85-101, 2009.

NAKANO, A.K. A produção da "cidade oca" nos padrões recentes de verticalização e adensamento construtivo do município de São Paulo. Revista Oculum Ensaios. Campinas, 2018. DOI: https://doi.org/10.24220/23180919v15n1a3373

NOGUEIRA, F. AND CANIL, K. Reflexões sobre a gestão de risco: Avanços e limitações. In: SULAIMAN, S. E JACOBI, P. (org) Olhares e saberes para a redução de risco de desastre. São Paulo: IEE-USP, 2018.

OKE, T.R., MILLS, G.; CHRISTEN, A., VOOGT, J.A. Urban Climates. Cambridge: Cambridge University Press, Cambridge, 2017.

OJIMA, R. Perspectivas para a Adaptação Frente às Mudanças Ambientais Globais no Contexto da Urbanização Brasileira: Cenários para os Estudos de População. Campinas: NEPO - Unicamp, 2009.

ONU. Urbanization and Development: emerging futures. Nairobi, Kenya: United Nations Human Settlements Programme, 2016.

PMJP [Lei Municipal Complementar 03/1994] - Lei do Plano Diretor da Cidade de João Pessoa. João Pessoa, PB: Câmara de Vereadores, 1994.

PMJP [Lei Municipal 054/2009] - Plano Diretor da Cidade de João Pessoa. João Pessoa, PB: Câmara de Vereadores, 2012.

QUARESMA, I.N. et al. Efetividade De Gestão Do Parque Estadual Do Jacarapé-PB. CONGRESSO BRASILEIRO DE GESTÃO AMBIENTAL E SUSTENTABILIDADE, v. 5. João Pessoa, PB. 2017. ISSN 2318-7603.

SANTOS, M. A Natureza do Espaço. São Paulo: Ed. Edusp, 4o edição, 1997.

SCHAEFFERA, R A et al. Energy sector vulnerability to climate change: A review. Energy, v. 38, I.1, p. 1-12, 2012. DOI: 10.1016/j.energy.2011.11.056

SILVA, G. et al. Lugares e suas interfaces: transformações urbanas e periferização. João Pessoa: Ed. UFPB, 2016.

SILVEIRA, J.A.R. et al. Dinâmica da cidade e bordas urbanas. João Pessoa: Ed. UFPB, 2015.

SMITH, A. A Riqueza das Nações. Coleção Os Economistas. São Paulo: Editora Nova Cultura, [1776] 1996.

SMITH, N. Desenvolvimento Desigual. Rio de Janeiro: Ed. Bertrand, 1998.

SOUZA, M. L. Mudar a Cidade: uma introdução crítica ao planejamento e à gestão urbanos. São Paulo: Ed Bertrand Brasil, 2001.

TUCCI, C. Águas urbanas. Revista Estudos Avançados v. 22, n. 63. São Paulo. 2008. Disponível em http://www. revistas.usp.br/eav/article/view/10295. Acesso em janeiro de 2020.

VIEIRA, J. ET AL. Green spaces are not all the same for the provision of air purification andclimate regulation services: The case of urban parks. Environmental Research, n. 160, p. 306-313, 2018. http://dx.doi.org/10.1016/j. envres.2017.10.006 